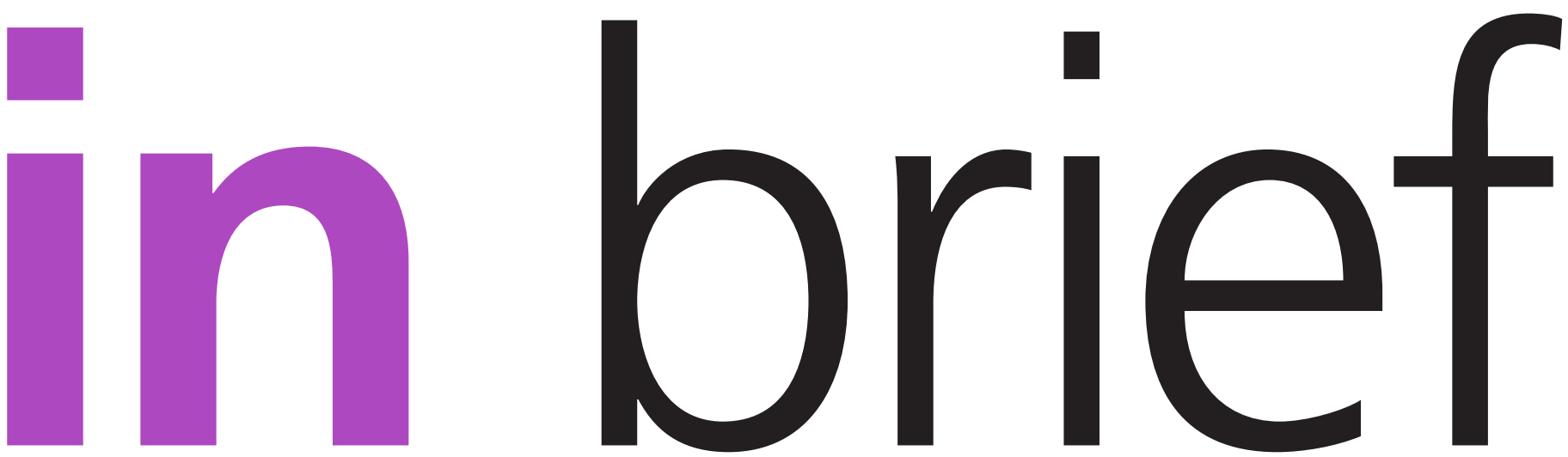

New Code of

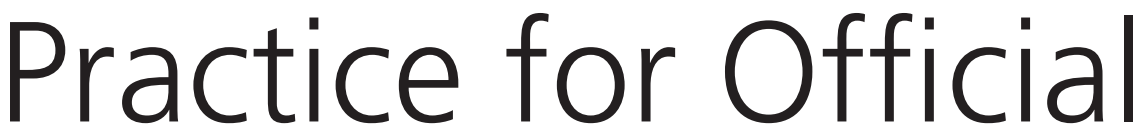

Statistics

The new Code of Practice for Official Statistics was published by the UK Statistics Authority on 6 January 2009.The Authority has statutory responsibility under the Statistics and Registration Service Act 2007 to prepare and publish this Code after due consultation.

The Code, along with a statement of the procedures to be followed in assessing statistics against it, was the subject of a 12 -week public consultation between July and September 2008 . Only those statistics the Authority judges to be compliant with the Code will be allowed to be designated as National Statistics in future.

Alongside the Code of Practice and the formal report on the consultation exercise, the Authority is publishing a further report which lists some 340 sets of official statistics not currently designated as National Statistics. The report identifies some of these statistics the Authority believes should be brought within the scope of the Code and assessed against it, with a view to designation as National Statistics. The Authority has a statutory duty to notify government ministers of such cases and will be following them up with the relevant government departments.

Just before Christmas, the Authority criticised a Home Office statement on knife crime statistics issued on 11 December. The Authority's analysis of this case appears in a paper prepared for the Authority's board at the time and was published on 6 January on the Authority's website. It draws out the ways in which the Home Office statement was inconsistent with the Code of Practice.
The Authority's Head of Assessment, Richard Alldritt, is responsible for assessing whether official statistics are compiled, released, and presented in a way that is consistent with the Authority's Code of Practice for Official Statistics, and whether to designate official statistics that have been assessed against the Code as National Statistics.

More information is available on the UK Statistics Authority website:

\section{Code of Practice}

www.statisticsauthority.gov.uk/assessment/ code-of-practice/index.html

Reports on the consultation exercise and on the priorities for designation as National Statistics www.statisticsauthority.gov.uk/reports--correspondence/reports/index.html

Individual responses to the consultation

www.statisticsauthority.gov.uk/reports--correspondence/consultations/closedconsultations/consultation-on-the-code-ofpractice-for-official-statistics--2008-.html

Monitoring and assessment note statement on knife crime statistics, 11December 2008 www.statisticsauthority.gov.uk/assessment/ monitoring-and-assessment-notes/publishednotes.html

\section{Cancer} survival in the Spearhead Primary Care Trusts of England

Figures for cancer survival in the Spearhead Primary Care Trusts (PCTs) of England, 1998-2005 were published by the Office for National Statistics (ONS) on 26 February 2009, on the Office for National Statistics website. These data update those published in September 2008 for 1998-2004. They have been produced in collaboration between the London School of Hygiene and Tropical Medicine and the National Cancer Intelligence Centre, ONS.

The 'Spearhead Group' of Local Authorities and Primary Care Trusts (PCTs) was selected by the Government in 2004 to be the focus of interventions to reduce health inequalities. The 70 Local Authorities, and 88 Trusts which mapped to them (now 62 PCTs following NHS reconfiguration in 2006) were chosen because they were in the lowest fifth in England for at least three of five key measures of health inequality - deprivation, male and female life expectancy, and mortality from cancer and cardiovascular disease.

The report compares one- and five-year survival from ten common cancers in patients resident in Spearhead PCTs, diagnosed during 2000-04 and followed up to the end of 2005, with those in the rest of England. These new data are presented along with an analysis of trends in survival over time. The report is available on the Office for National Statistics website at: www.statistics.gov.uk/statbase/Product. asp?vlnk=14821 
A more detailed assessment of trends in cancer survival in Spearhead PCTs is given in the article on page 7 of this edition of Health Statistics Quarterly.

\section{Suicides 2007}

An annual update on the number and rates of suicide in the UK, including data for 2007, was published by ONS on 27 January 2009

Suicide rates in both men and women in the UK continued to fall in 2007, reaching their lowest level since 1991. The suicide rate for men in 2007 was 16.8 per 100,000 and this has steadily fallen from a peak in 1998 of 21.1 per 100,000 . For women the rate was 5.0 per 100,000 in 2007 and rates have been consistently much lower than those of men. In recent years the highest suicide rates in men have been in those aged 15-44, while the highest rates among women have been in those aged 45-74

Information is available on the Office for National Statistics website at: www.statistics.gov.uk/cci/nugget.asp? $\mathrm{id}=1092$ www.statistics.gov.uk/statbase/Product. asp?vlnk $=13618$

\section{Alcohol-related deaths 2007}

The number and rate of alcohol-related deaths in the UK were published by ONS on 27 January 2009, including data for 2007 .

The trend in alcohol-related deaths is now levelling out following rapid increases since the early 1990s. There were 8,724 alcohol-related deaths in the UK in 2007, lower than in 2006, but more than double the 4,144 recorded in 1991. In 2007 the alcohol-related death rate for all persons was 13.3 per 100,000 , compared with 6.9 per 100,000 in 1991 . The alcoholrelated death rate in men was 18.1 per 100,000 in 2007 , more than double the rate of 8.7 per 100,000 for women. The death rate for men has almost doubled from 9.1 per 100,000 in 1991 while there has been steadier increase in the female rate, rising from 5.0 per 100,000 in 1991.

Information is available on the Office for National Statistics website at: www.statistics.gov.uk/cci/nugget.asp?id=1091 www.statistics.gov.uk/statbase/Product. asp?vlnk=14496

\section{Smoking and drinking behaviour and attitudes}

Two annual reports on smoking and drinking behaviour and attitudes were published by ONS on 22 January 2009. They were: Smoking and drinking among adults 2007, taken from the General Household Survey (GHS) 2007 and Drinking: adults' behaviour and knowledge in 2008, taken from the Opinions (Omnibus) survey.

Current advice on drinking is that men should not drink regularly more than three to four units of alcohol and women should not drink regularly more than two to three units. In 2007 , 37 per cent of adults (41 per cent of men and 34 per cent of women) exceeded the recommended daily limits for regular drinking on at least one day during the week before interview and 20 per cent of adults ( 24 per cent of men and 15 per cent of women) consumed more than double the benchmark on their heaviest drinking day of the week. The report also shows that more people in 'managerial and professional' households exceeded the daily limit on their heaviest drinking day of the week (43 per cent) than those in 'routine and manual' households (31 per cent).

The downward trend in smoking continued in 2007 , with the overall prevalence of cigarette smoking among adults at its lowest recorded level of 21 per cent ( 22 per cent for men and 20 per cent for women). Smoking is most prevalent in the 20-24 age group (31 per cent) and becomes less prevalent as age increases, falling to 12 per cent of those aged 60 and over In contrast to drinking, smoking was highest in households classified as 'routine and manual', where 27 per cent of adults smoked. Prevalence was lowest among those in 'managerial and professional' households at 15 per cent.

The ONS Opinions (Omnibus) Survey Drinking: adults' behaviour and knowledge in 2008 asked people about where they drank on their heaviest drinking day in the previous week. The home was the most common place for alcohol consumption on that day, 45 per cent for men and 60 per cent for women.

The two reports are available on the Office for National Statistics website at:

Smoking and drinking among adults 2007 www.statistics.gov.uk/statbase/Product. asp? $\operatorname{vlnk}=5756$

Drinking: adults' behaviour and knowledge in 2008

www.statistics.gov.uk/statbase/Product. asp? $\mathrm{vlnk}=6990$

\section{Summary of children in the Millennium Cohort aged five}

The Millennium Cohort Study (MCS) interviewed over 15,000 children aged five across the UK and published a full report and initial findings in October. Data include responses from both parents, direct assessments of the cohort child's cognitive development and physica growth as well as evidence from teachers.

At the age of five over three-quarters of Study children were living with both of their natural parents, the majority of whom were married. A minority of five-year-olds were living with either a lone mother (17 per cent) or a natural mother and a step-father (4 per cent). The most common family change for this cohort between sweeps one (starting June 2001) and three (ending early 2007) was the arrival of a younger sibling, which happened in four families out ten.

The majority of Study children were in good health at the age of five, but there were differences across socio-economic groups. Poor children fared substantially worse than others in terms of both their reported level of general health and specific conditions.

In general boys fared worse than girls in terms of many health outcomes, and the gap was widest on variables such as speech problems and bedwetting, which reflect failure to achieve developmental milestones. Girls were more likely to be overweight or obese than boys at the age of five - as they had also been at the age of three.

Measurements of Body Mass Index puts overweight and obesity at 22 per cent overall at five, but suggests they are more weakly associated with economic inequality than many other health outcomes.

The full report Millennium Cohort Study Third Survey: A User's Guide to Initial Findings published in October 2008 is available at: www.cls.ioe.ac.uk/news.asp? section $=00010001$ 0003\&item $=473$ 


\section{Recent and forthcoming ONS releases}

\section{Recent releases}

9 December

Birth Statistics 2007 (FM1 no. 36)

www.statistics.gov.uk/statbase/Product.asp?vlnk=5768

9 December

Population Trends No. 134 Winter 2008

www.statistics.gov.uk/statbase/Product.asp?vlnk=6303

Print copies available from Palgrave Macmillan 01256357893

\section{December}

Cancer Statistics 2006 (MB1 no. 37)

www.statistics.gov.uk/statbase/Product.asp?vlnk=8843

\section{January}

Drinking: adults' behaviour and knowledge in 2008

www.statistics.gov.uk/statbase/Product.asp?vlnk=6990

\section{January}

Smoking and drinking among adults, 2007

www.statistics.gov.uk/statbase/Product.asp?vlnk=5756

27 January

Alcohol-related deaths in the UK, 2007

www.statistics.gov.uk/statbase/Product.asp?vInk=14496

\section{January}

Suicide rates in the UK, 2007

www.statistics.gov.uk/statbase/Product.asp?vlnk=13618

\section{February}

Marriages 2007 in England and Wales

www.statistics.gov.uk/statbase/Product.asp?vlnk=14275

\section{February}

Congenital anomaly notifications 2007 (MB3 no. 22)

www.statistics.gov.uk/statbase/Product.asp?vlnk=5799

\section{February}

Cancer Survival in the Spearhead Primary Care Trusts of England, 1998-2005

www.statistics.gov.uk/statbase/Product.asp?vlnk=14821

\section{February}

Annual conceptions 2007: provisional

www.statistics.gov.uk/statbase/Product.asp?vlnk=15055

\section{February}

UK Electoral Statistics, 2008

www.statistics.gov.uk/statbase/Product.asp?vlnk=319

\section{Forthcoming releases}

26 March

Population Trends No. 135 Spring 2009

www.statistics.gov.uk/statbase/Product.asp?vlnk=6303

Print copies available from Palgrave Macmillan 01256357893

\section{March (provisional)}

Marriages, divorces and adoptions 2006 (FM2 no. 34)

www.statistics.gov.uk/statbase/Product.asp?vInk $=581$

\section{March (provisional)}

Mortality statistics: childhood, infant and perinatal 2006 (DH3 no. 40) www.statistics.gov.uk/statbase/Product.asp?vlnk=6305

\section{March}

National population projections by marital status, 2006-based

\section{April}

Social Trends No. 392009 edition

www.statistics.gov.uk/statbase/Product.asp?vlnk=5748

Print copies available from Palgrave Macmillan 01256302611

For further information, contact the ONS Customer Contact Centre

0845601 3034, email info@statistics.gsi.gov.uk

\section{Correction:} Health Statistics Quarterly 40 Winter 2008

Page 91 Report: Cancer incidence and mortality in the United Kingdom and constituent countries, 2003-05
Errors have been found in the number of deaths reported for two cancer sites. These have been corrected and revised figures are presented below. These corrections affect the text on pages 91 and 95 .

Page 91, last paragraph - 2nd sentence should read 'However, for females the mortality rate was lower for breast than for lung cancer (29 and 30 per 100,000 respectively).'

Page 95, last paragraph - last sentence should read 'The incidence and mortality rates for breast cancer were the lowest in the UK.'
Table 2 Deaths from cancer and directly age-standardised mortality rates per 100,000 population: selected sites by sex and country, 2003-05

\begin{tabular}{l|c|c|c|r|r|r}
\hline & $\begin{array}{c}\text { Site } \\
\text { descrip- } \\
\text { ICD-10 }\end{array}$ & Sex & \multicolumn{2}{|c|}{$\begin{array}{c}\text { United } \\
\text { Kingdom }\end{array}$} & \multicolumn{2}{|c}{ N Ireland } \\
\hline & & & Number & Rate & Number & Rate \\
\hline C50 & Breast & F & 12,525 & 28.6 & 304 & 28.0 \\
C62 & Testis & M & 82 & 0.3 & 2 & 3 \\
\hline
\end{tabular}

3 Directly age-standardised rates were considered unreliable and were not calculated when there were fewer than 20 deaths over three years in an area. 